\title{
In Vitro-Propagation of Agave tequilana Weber cv. azul in a Temporary Immersion System
}

\author{
Otilio Vázquez-Martínez ${ }^{1}$, Héctor Gordon Núñez-Paleniuss ${ }^{1, *}$, Eugenio M. Pérez-Molphe Balch ${ }^{2, *}$, \\ Mauricio Valencia-Posadas ${ }^{1}$, Luis Pérez-Moreno ${ }^{1}$, Graciela M. L. Ruiz-Aguilar ${ }^{1}$ and M. Gómez-Lim ${ }^{3}$ \\ ${ }^{1}$ División de Ciencias de la Vida, Universidad de Guanajuato, Irapuato, 36500, México \\ ${ }^{2}$ Departamento de Química, Centro de Ciencias Básicas, Universidad Autónoma de Aguascalientes, Aguascalientes, 20131, México \\ ${ }^{3}$ Departamento de Ingeniería Genética, CINVESTAV Unidad Irapuato, Irapuato, 36500, México \\ ${ }^{*}$ Corresponding Authors: Héctor Gordon Núñez-Palenius. Email: palenius@ugto.mx; Eugenio M. Pérez-Molphe Balch \\ Email: eperezmb@correo.uaa.mx
}

Received: 28 April 2021 Accepted: 01 July 2021

\begin{abstract}
In Mexico, there is a need to produce large quantities of plantlets for the establishment and replanting of blue (cv. azul) agave production areas. Most of these plots are within the origin denomination area (DOT, Spanish acronym) of the distilled product of this plant, known as tequila. The objective of this study was to develop an in vitropropagation protocol for Agave tequilana Weber cv. azul using segmented stems in both: solid and liquid media. A disinfection and in vitro technique were developed to obtain shoots, through plantlets collected in commercial plots, which attained $100 \%$ surface-disinfection and budding rate. At the multiplication stage, the effects of 6-Benzylaminopurine (BA) $(0.0,4.4$ and $13.2 \mu \mathrm{M})$ and kinetin $(0.0,9.4,18.8$ and $37.6 \mu \mathrm{M})$ were evaluated on lateralshoot production of segmented sagittal stems. These were cultivated on Murashige \& Skoog (MS) medium, with the addition of $3.0 \%$ sucrose and $8 \mathrm{~g} \mathrm{~L}^{-1}$ agar. It was observed that BA and kinetin increased the number of shoots per explant, obtaining up to 18 and 26, respectively. Furthermore, it was found that just the sagittal segmentation of explants increased axillary budding. On the other hand, segmented-stem bases were grown in MS liquid medium with $3.0 \%$ sucrose, inside a RITA $^{\circledR}$ system, programmed by a 5 min immersion step with a frequency of every $4 \mathrm{~h}$. The effect of Indole-3-Acetic acid (IAA) $(0.57,2.9,5.7 \mu \mathrm{M})$ was evaluated, while maintaining a concentration of BA $(13.2 \mu \mathrm{M})$. It was observed that the greatest concentration of IAA led to the formation of more than 20 buds per explant. These results offer a new methodology to increase the efficiency of A. tequilana Weber cv. azul-in vitro multiplication by sagittal segmentation of stems and the addition of BA and/or IAA.
\end{abstract}

\section{KEYWORDS}

Plant tissue culture; stem-disk culture; tequila; in vitro culture

\section{Introduction}

The cultivation zone for Agave tequilana Weber cv. azul in Mexico requires increased areas, due mostly to the greater national and international demand for Tequila, which is the distillate from that plant. If this is not achieved, there will be a shortage of agave plant heads. The growth of this crop in the origin denomination area (DOT, Spanish acronym) has generated the need to develop more efficient ways for 
multiplying the Agave tequilana plantlets, which must comply with the conditions of agro-industrial production. The in vitro-culture technique is an alternative that allows the annual production of large numbers of plants in small laboratory spaces, maintaining their genetic stability [1-3]. There are several reports on micropropagation of various Agave species, through distinctive systems of plant regeneration [4]. Plants were obtained by direct organogenesis from callus tissue [3,5-10]. Multiple shoots were induced through basal meristems; and embryogenesis and indirect organogenesis were also used [11-17]. Furthermore, plants were regenerated by direct organogenesis from stem tissues [18]. Somatic embryogenesis was also induced, and several plants were obtained [19-22]. In addition to micropropagation, there are reports on the production of secondary metabolites by cultures of callus tissue $[16,23,24]$.

There are challenges in the agave-in vitro culture that have influenced the micropropagation efficiency for different species, which have required optimization. For example, through the establishment stage, the need to transplant selected plants from the field to greenhouse conditions has been mentioned. Fungicides and bactericides were applied during preconditioning or during surface disinfection to reduce in vitro contamination $[9,11,16]$. In the multiplication stage, the proliferation procedures were developed in a complex way, and, in most cases, they were initiated from calli derived from leaves, stems or apex tissues. Once these calli were produced, their adventitious shoots were induced to generate different multiplication rates. This induction depended on the combined use of 2, 4-D and cytokinins at different levels $[6,7,9,11,21]$, cytokinins alone [12,17], and cytokinins and auxins [10,16].

On the other hand, there are indications that the protocols for Agave micropropagation are based on high costs. This justifies the modification of methods through organogenesis, to achieve an efficient and costeffective multiplication protocol at a large scale [1]. In other plant species, it was demonstrated that these costs can be reduced through automation processes, such as the application of temporary immersion bioreactors [4,25-28]. Among these systems, the RITA ${ }^{\circledR}$ (Automated Temporary Immersion System), due to its applications and benefits [29], was used in different optimization processes for micropropagation [30-33]. This system consists of a single container that has two compartments separated by a tray with a net, where the explants are kept; then, through a pneumatic mechanism, the explants are intermittently exposed to a liquid-air interface. Its principle and efficiency were compared with other systems [34-37].

The two most important benefits offered by blue agave in vitro culture are related to the multiplication efficiency and the guarantee of phytosanitary conditions. Firstly, the Agave spp. micropropagation allows the production of clonal lines and several thousand plants from a single mother agave plant within 12 months vs. a few tens of plants that the same plant will produce in the 6th year of its life cycle. The Agave in vitro culture results in high-quality, high-yielding materials that produce a significant increase in yield at the plantation stage [14]. Secondly, the sterile conditions of nutritive media and the aseptic techniques for establishment and multiplication, allow to keep axenic-in vitro tissue cultures. There are also techniques that facilitate to remove diseases produced by endogenous microorganisms, including viruses [38]. For Agave tequilana Weber cv. azul the phytosanitary condition is especially important since the clonal condition of plantations favors the disease-spreading, which can have profound effects on the availability of material for plantations and on the crop productivity in the field [15].

Since almost 35 years ago, Robert et al. [14] defined a protocol reported as an efficient method to micropropagate agaves and a strategy for the management of large-scale production that has been successfully applied to A. tequilana Weber cv. azul and several other Agave species. This scheme has formed the basis for the development of other methodologies to improve that efficiency, mainly aimed at exceeding multiplication rates. This is the main source of information for companies dedicated to the production of agave plantlets. Although none of the research reports mention the cost per micropropagated plantlet (Tab. 1), the efforts in such studies suggest an optimization in the cost of inputs 
and in the process technique. Our study did not estimate the degree of cost reduction in the developed methodology, but, based on the comparison with the materials and methodologies reported, it proposes a level of multiplication efficiency higher than them. This suggests possible cost savings for $A$. tequilana Weber cv. azul up to the stage of micropropagation that is addressed in this study. On the other hand, the information that the companies have shared with the public reflects a level of technology transfer derived from the referred investigations. For example, in Mexico there is a company that reports having achieved the massive propagation of more than 22 million in vitro blue agave plants. It also offers to guarantee the supply of "elite" material for tequila industry, and mentions a quantity of losses after transplantation in a range of less than $2 \%$. In addition, this company reports having reached harvest in five years, with an average content of reducing sugars between 20-24 percent in the harvestable product [39]. This shows that the potential of the micropropagation technique can meet the needs that intense industrial activity requires.

Table 1: Reported methods to improve the Agave species multiplication rate by direct bud and shoot formation

\begin{tabular}{|c|c|c|c|}
\hline Agave species & Plant growth regulators/type of explant & Multiplication efficiency & Reference \\
\hline A. fourcroydes & $\begin{array}{l}2,4-\mathrm{D}(0.11 \mu \mathrm{M}) \text { and } \mathrm{BA}(44 \mu \mathrm{M}) / \text { rhizome } \\
\text { segments }\end{array}$ & $1-6$ shoots per explant/12 weeks & {$[6]$} \\
\hline $\begin{array}{l}\text { A. cantala } \\
\text { Roxb. }\end{array}$ & $\begin{array}{l}\text { NAA }(0.41 \mu \mathrm{M}) \text {, IBA }(0.49 \mu \mathrm{M}) \text { and Kinetin } \\
(2.35 \mu \mathrm{M}) / \text { Shoots from rhizome }\end{array}$ & 4.86 shoots per bud/40 days & {$[11]$} \\
\hline Agave sisalana & $\begin{array}{l}60 \text { days Induction BA }(22.2 \text { and } 44.0 / \mu \mathrm{M}) ; 1 \text { st. } \\
60 \text { days subculture on BA }(22.2 \mu \mathrm{M}) ; 2 \text { nd. } 60 \text { days } \\
\text { subculture on BA }(2.2 \text { or } 4.4 . \mu \mathrm{M}) / \text { rhizome } \\
\text { segments }\end{array}$ & $8-12$ buds and shoots/120 days & {$[12]$} \\
\hline $\begin{array}{l}\text { A. sisalana } \\
\text { Perrine }\end{array}$ & Kinetin $(2.35 \mu \mathrm{M}) /$ rhizome segments & 5.7 shoots (time not reported) & {$[40]$} \\
\hline $\begin{array}{l}\text { A. parrasana } \\
\text { Berger }\end{array}$ & $\begin{array}{l}\text { BA }(53.2 \mu \mathrm{M}) / \text { Shoots from in vitro germinated } \\
\text { seeds }\end{array}$ & 48.6 shoots per explant/60 days & {$[13]$} \\
\hline $\begin{array}{l}\text { A. victoriae- } \\
\text { reginae }\end{array}$ & $\begin{array}{l}\text { BA }(2.2-8.8 \mu \mathrm{M}) / \text { Stem bases from in vitro } \\
\text { germinated seeds }\end{array}$ & 1.9-2.2 shoots per explant/12 weeks & {$[41]$} \\
\hline $\begin{array}{l}\text { Agave } \\
\text { salmiana } \\
\text { Gentry }\end{array}$ & $\begin{array}{l}\text { IAA/BA }(1.43 / 8.8 \mu \mathrm{M}) / 2-3 \mathrm{~mm} \text {-thick discs } \\
\text { sectioned from the stem core. }\end{array}$ & $\begin{array}{l}\text { Propagation via regeneration of } 20 \text { shoots per } \\
\text { explant } / 45 \text { days }\end{array}$ & {$[16]$} \\
\hline Agave spp. & $\begin{array}{l}\text { A. oscura IBA/BA }(2.46 / 4.44 \mu \mathrm{M}) \text {. } \\
\text { A. tequilana Pulses with } 2,4-\mathrm{D}(6.8 \mathrm{mM}-3 \mathrm{~d}) \text {; } \\
\text { subculture on } 2,4-\mathrm{D} / \mathrm{BA}(0.113 \mu \mathrm{M} ;+4.44 \mu \mathrm{M} \mathrm{BA}) \\
\text { or BA/NAA } \\
\text { A. duranguensis IBA/BA }(0.049 / 4.44 \mu \mathrm{M}) \\
\text { A. pigmaea } \mathrm{IBA} / \mathrm{BA}(0.049 / 13.31 \mu \mathrm{M}) \\
\text { A. victoria-reginae. IBA/BA }(2.46 / 2.22 \mu \mathrm{M}) \\
\text { A. salmiana subspecies crassispina } \mathrm{IBA} / \mathrm{BA}(0.49 / \\
4.44 \mu \mathrm{M}) \\
\text { In all species, the explants were complete stem } \\
\text { cores established from young plants }\end{array}$ & $\begin{array}{l}12.8 \text { shoots } / 60 \text { days } \\
12.0 \text { shoots } / 30-60 \text { days after a pulse of } 1- \\
6 \text { days } \\
5.9 \text { shoots } / 60 \text { days } \\
5.6 \text { shoots } / 60 \text { days } \\
5.5 \text { shoots } / 60 \text { days } \\
3.0 \text { shoots } / 60 \text { days }\end{array}$ & {$[9]$} \\
\hline Agave spp. & $\begin{array}{l}\text { A. cupreata and } A \text {. karwinskii (BA } 6.6 \text { and } 4.4 \mu \mathrm{M}) \text {. } \\
\text { A. difformis and A. obscura (TDZ } 0.9 \mu \mathrm{M}) \text {. } \\
\text { A. potatorum (kinetin } 14.1 \mu \mathrm{M}) \text {. } \\
\text { In all species, the explants were shoot bases from in } \\
\text { vitro germinated seeds. }\end{array}$ & $\begin{array}{l}10.5-6.1 \text { shoots per explant } / 12 \text { weeks } \\
8.5-11 \text { shoots per explant } / 12 \text { weeks } \\
6.9 \text { buds per explant } / 12 \text { weeks }\end{array}$ & {$[17]$} \\
\hline
\end{tabular}


Table 1 (continued)

\begin{tabular}{|c|c|c|c|}
\hline Agave species & Plant growth regulators/type of explant & Multiplication efficiency & Reference \\
\hline A. tequilana & $\begin{array}{l}\text { IBA }(0.246 \mu \mathrm{M}) \text { y Kinetin }(46.46 \mu \mathrm{M}) / \text { Shoot apex } \\
\text { from young plants. }\end{array}$ & 3.67 shoots $/ 4$ weeks & {$[10]$} \\
\hline $\begin{array}{l}\text { A. tequilana, } \\
\text { A. angustifolia, } \\
\text { A. applanata, } \\
\text { A. salmiana, } \\
\text { A. colimana, } \\
\text { A. victoria- } \\
\text { reginae, } \\
\text { A. inaequidens, } \\
\text { A. maximiliana }\end{array}$ & $\begin{array}{l}\text { Authors offer a proven protocol for these species. } \\
\text { BA }(0-52.8 \mu \mathrm{M}) \text { and } 2,4-\mathrm{D}(0.04-0.11 \mu \mathrm{M}) / \\
\text { Rescued zygotic embryos, apex }(5 \mathrm{~mm}) \text { and bulbils. }\end{array}$ & $\begin{array}{l}\text { Authors ensure } 3-6 \text { shoots using composed } \\
\text { explants ( } 2-3 \text { shoots }) / 4 \text { weeks; according to } \\
\text { the species and/or variety. }\end{array}$ & {$[3]$} \\
\hline
\end{tabular}

Based on the aforementioned facts, the objective of this research was to develop a more efficient system for the in vitro propagation of Agave tequilana Weber cv. azul, through the cultivation of segmented stems. The results obtained demonstrate a significant increase in multiplication efficiency on a semi-solid medium and in a RITA ${ }^{\circledR}$ system. Up to our knowledge, both results have not been reported for this species and variety of Agave using segmented stems.

\section{Materials and Methods}

\subsection{Establishment of Aseptic Cultures}

The technique of establishing Agave tequilana Weber cv. azul in vitro cultures was implemented according to the procedure for garlic micropropagation by cultivating segmented-stem discs, defined by Ayabe et al. [42]. The principles applied for the multiplication of bulbous species by traditional methods such as scooping, and scoring were as described by Hartman et al. [43] and Miller et al. [44].

Agave plants, of approximately 2-3-year-old, were obtained from plantations located in the DOT, and these plants had on average stem base size of $10.0 \pm 2.0 \mathrm{~cm}$ diameter. The bulbous bases of the plants were reduced in size by sagittal segmentation, until internal basal stem segments of $4.0 \pm 1.0 \mathrm{~cm}$ long and $2.0 \pm$ $1.0 \mathrm{~cm}$ wide were obtained. These basal segments were rinsed for one minute with tap water, adding $0.2 \%$ of Extran ${ }^{\circledR}$ MA 02 detergent (Merck, Mexico). Then, they were rinsed to remove the detergent, and the excess water was dried using sterile paper towels. Under aseptic conditions, the basal segments were reduced in size, until obtaining central portions of the stem, with a diameter of $1.0-1.5 \mathrm{~cm}$. Subsequently, these segments were surface disinfected by stirring in ethanol $(80 \% \mathrm{v} / \mathrm{v})$ for $1 \mathrm{~min}$, and then, by gently stirring in a commercial solution of Cloralex ${ }^{\circledR}$ bleach $(\mathrm{NaOCl})(20 \% \mathrm{v} / \mathrm{v})$ for $15 \mathrm{~min}$, adding $0.02 \%$ Tween $80^{\circledR}$ (Phytotechnology Laboratories, KS. USA). Later, they were rinsed three times, $30 \mathrm{~min}$ each, with sterile distilled water to remove chlorine and detergent. Finally, the agave cylinders were cut, using an Olympus SZ60 stereoscopic binocular microscope (USA) at 15X magnification, to obtain 3.0-5.0 mm diameter stem discs, so each final explant had $1.0 \mathrm{~mm}$ from the base of the stem and $1.0 \mathrm{~mm}$ for the cataphylebases. Each stem disc was sagittally segmented into four parts, so that the cut passed through the center of the disc. Each fragment was then placed vertically on Murashige and Skoog basal medium (MS) containing 3.0\% sucrose and $8.9 \mathrm{~g} \mathrm{~L}^{-1}$ agar (Phyto Technology Laboratories, KS, USA). To prepare this medium, the $\mathrm{pH}$ value was adjusted to 5.8 ( $\mathrm{pH} / \mathrm{ORP} / \mathrm{ISE}$, HI98191 Hanna meter, Mexico) before adding the agar. The medium was sterilized at $121^{\circ} \mathrm{C}$ for $15 \mathrm{~min}$. The addition in the medium of BA $(0.0,4.4$, $8.8,13.2,17.6 \mu \mathrm{M})$ and zeatin $(0.0,4.6,9.2,13.8,18,4 \mu \mathrm{M})$ was evaluated in conjunction. The explants were incubated at $25 \pm 1.0^{\circ} \mathrm{C}$ under a $32 \mu \mathrm{mol} \mathrm{m}^{-2} \mathrm{~s}^{-1}$ illumination and a $16 \mathrm{~h}$ photoperiod of light. Each treatment consisted of six repetitions, where each one was represented by an explant (stem disk) divided 
into four segments in each culture container. The evaluation was carried out after 12 weeks of cultivation. The variables measured corresponded to the percentage of contamination and the number of shoots per explant.

\subsection{Multiplication on Solid Medium}

The multiplication technique was implemented considering the use of MS medium, and the type and range of effective concentrations of single cytokinins or combined with auxins, according to Binh et al. [11]; Ramírez-Malagón et al. [9] and Silos-Espino et al. [16]. The differences of this study in comparison to those published consisted in the cultivation of sagittal segmented-stem bases as explants, and the avoidance of using 2,4-D as auxin.

For this stage of multiplication on semisolid medium, in vitro established plants were selected, and individual shoots $(6-8 \mathrm{~cm}$ long and $1.0 \pm 0.2 \mathrm{~cm}$ in diameter) were utilized. The leaves were removed, and four segments were obtained from the cylindrical portions of the stem bases. These were placed in a horizontal position, with the segmented section in contact with the MS medium, which contained 3.0\% sucrose and $8.0 \mathrm{~L}^{-1}$ agar. The $\mathrm{pH}$ was adjusted to 5.8 before adding the agar. The BA $(0.0,4.4$ and $13.2 \mu \mathrm{M})$ and kinetin $(0.0,9.4,18.8$ and $37.6 \mu \mathrm{M})$ were added independently to the medium. Explants were incubated at $25 \pm 1.0^{\circ} \mathrm{C}$ under an illumination of $32 \mu \mathrm{mol} \mathrm{m} \mathrm{m}^{-2} \mathrm{~s}^{-1}$ and a photoperiod of $16 \mathrm{~h}$ light. Each treatment consisted of four and three repetitions for BA and kinetin, respectively. Each repetition was represented by an explant (stem disk) divided into four segments, inside a culture flask and containing $20 \mathrm{ml}$ of culture medium. After six weeks of culture, observations were carried out. The variable measured was the number of shoots per explant.

\subsection{Multiplication in a Temporary Immersion System}

For the A. tequilana Weber cv. azul multiplication in the RITA ${ }^{\circledR}$ temporary immersion system, the MS medium was used, and the immersion cycle and culture conditions were based on Ramos-Castellá et al. [45]. The shoots (10-15 cm in length) established on solid medium were used. From these, lateral basal portions measuring $1.0 \mathrm{~cm}$ length and $1.0 \mathrm{~cm}$ diameter were taken from the stem. The explants were sagittal sectioned, obtaining four segments per explant, and placed into an automatic temporary immersion system $\left(\right.$ RITA $\left.^{\circledR}\right)$. All treatments including BA $(13.2 \mu \mathrm{M})$ and three IAA concentrations $(0.57,2.9$, $5.7 \mu \mathrm{M})$ were evaluated. To each RITA $^{\circledR}$ container, $300 \mathrm{ml}$ of liquid MS medium with $3 \%$ sucrose were added. The immersion time was programmed at $5 \mathrm{~min}$ with a frequency of every $4 \mathrm{~h}$. The explants were incubated at $25 \pm 1.0^{\circ} \mathrm{C}$, under an illumination of $32 \mu \mathrm{mol} \mathrm{m} \mathrm{m}^{-2} \mathrm{~s}^{-1}$ and a photoperiod of $16 \mathrm{~h}$ light. Each RITA $^{\circledR}$ represented one treatment, and each treatment had six explants sectioned into four segments.

A normality analysis was carried out for the data according to the Shapiro-Wilk method in all experiments. For the establishment stage's evaluation, given the similarities among the cytokinins $(\mu \mathrm{M})$ concentrations, an analysis of variance was conducted for a factorial design with a completely random arrangement, evaluating two factors: Plant Growth Regulators and their levels. For the other experiments,

a simple analysis of variance was conducted according to a completely random arrangement. The means separation in all experiments was performed with the Tukey test $(P \leq 0.05)$.

\section{Results and Discussion}

\subsection{Establishment of Aseptic Cultures}

After 12 weeks, the segmented-stem explants generated multiple shoots, greater than $3 \mathrm{~mm}$ tall in each treatment, with and without cytokinins. BA and zeatin had differences in the induction of shoot number per explant $(P=0.0000)$. Likewise, it was observed that the increase in the concentration of cytokinin produced a greater shoot number $(P=0.0000)$, in the range of the evaluated concentrations (Tab. 2). 
Table 2: Effect of BA and zeatin on shoot production in segmented-stem explants of A. tequilana Weber cv. azul after 12 weeks

\begin{tabular}{ll}
\hline BA-Zeatin $(\mu \mathrm{M})$ & Shoots per explant* \\
\hline $0.0-0.0$ & $3.00 \pm 0.47 \mathrm{a}$ \\
$4.4-4.6$ & $6.66 \pm 0.68 \mathrm{~b}$ \\
$8.8-9.2$ & $7.00 \pm 0.83 \mathrm{~b}$ \\
$13.2-13.8$ & $9.66 \pm 1.25 \mathrm{bc}$ \\
$17.6-18.4$ & $12.41 \pm 1.50 \mathrm{c}$ \\
\hline
\end{tabular}

*Note: Average values \pm standard error, with distinctive letters within the column to the right are significantly different (Tukey; $\alpha=0.05$ ).

The results obtained using agave segmented stems as explants are similar to those reported in other species by cultivating bulbous and rosette stems, generated from the apex or axile of rhizomes. Xue et al. [46] described the in vitro formation of embryogenic garlic calli from the basal plate in bulbs that conserved the apex and in aerial bulbs. In this same species, Ayabe et al. [42] demonstrated that the in vitro culture of segmented stem discs could increase the multiplication efficiency, compared to other methods. They also observed that the proliferation response was independent of the exogenous addition of BA and/or NAA. In the Agave genus, the regenerative capacity of basal tissues for in vitro establishment has been demonstrated. For instance, central stem tissue has been cultured by sagittal segmentation in A. cantala Roxb., A. fourcroydes Lem. and A. sisalana Perrine [11]; however, this was achieved by indirect regeneration of adventitia buds. Lateral sprouting has also induced through transversal segmentation of stems in A. salmiana Gentry [16]. In most reports, budding and shooting were induced by growing whole stems containing the apex and the stem's inner base. In our research, according to the high percentage of surface disinfection and sprouting, 100 percent of the responses observed were uniform in both: the aseptic establishment and the lateral sprouting capacity during this stage.

The direct axillary shooting in segmented stems of $A$. tequilana Weber cv. azul, compiles the postulations of the apical dominance phenomenon that derives from the presence of auxins at the apex, which by elimination, such as decapitation, can be reversed [47,48]. Due to the addition of exogenous cytokinins, lateral budding is promoted [49]. Regarding the addition of auxins for the different Agave species, most of the micropropagation reports are based on the whole apex culture in the presence of 2,4$\mathrm{D}$, generally with the addition of BA. This has increased indirect budding of the adventitia and, subsequently, lateral shoot proliferation [6,7,9-12,16,17,21]. This effect confuses the distinction of the origin of the organogenic response. Furthermore, only limited research was reported to determine the genetic status of sprouts [50-52]. In addition, it was observed that in different cell explants used to induce somatic embryogenesis, 2,4-D increased the appearance of cytogenetic abnormalities, related to different levels of somaclonal variation [53].

\subsection{Multiplication in Solid Medium}

After six weeks of culture, the number of shoots per explant was evaluated. It was observed that the addition of BA $(P=0.0018)$ and kinetin $(P=0.0001)$ increased the number of lateral shoots. While the lack of BA induced three shoots per explant, the addition of this cytokinin $(8.8-13.2 \mu \mathrm{M})$ induced the formation of up to 18 shoots (Tab. 3). The control treatment for kinetin induced the formation of four shoots per explant, and the addition of this cytokinin $(9.4-37.6 \mu \mathrm{M})$ induced the formation of up to 26 shoots. These responses demonstrated that the sagittal cut and segmentation of the explant itself promoted lateral dominance and multiple shooting (Fig. 1). This axillary shooting response, given this type of explant and the effects of phytohormones, up to our knowledge, has not been previously reported 
in Agave [3,4,10,11,16]. Nonetheless, Silos-Espino et al. [16] reported that stem discs obtained by transversal segmentation of $A$. salmiana Gentry explants, produced less than two shoots per explant when placed on MS medium containing IAA $0.25 \mathrm{mg} \mathrm{L}^{-1}$. In our results, the addition of BA and kinetin significantly increased the proliferation of lateral shoots (Tab. 3).

Table 3: Effect of two cytokinins (BA and kinetin) on axillary proliferation in A. tequilana Weber cv. azul segmented stems, after 6 weeks of in vitro culture

\begin{tabular}{ll}
\hline BA $(\mu \mathrm{M})$ & Shoots per explant* \\
\hline 0.0 & $3.0 \pm 0.81 \mathrm{a}$ \\
4.4 & $11.7 \pm 1.60 \mathrm{~b}$ \\
13.2 & $18.2 \pm 3.06 \mathrm{~b}$ \\
\hline Kinetin $(\mu \mathrm{M})$ & Shoots per explant* \\
\hline 0.0 & $4.3 \pm 0.88 \mathrm{a}$ \\
4.7 & $19.7 \pm 2.02 \mathrm{~b}$ \\
9.4 & $22.7 \pm 2.33 \mathrm{~b}$ \\
37.6 & $26.7 \pm 1.76 \mathrm{~b}$ \\
\hline
\end{tabular}

Note: *Shapiro-Wilk Test: BA, $P=0.11$; kinetin $P=0.50$. Average values \pm standard error with distinctive letters within the column to the right, are significatively different (Tukey; $\alpha=0.05$ ).

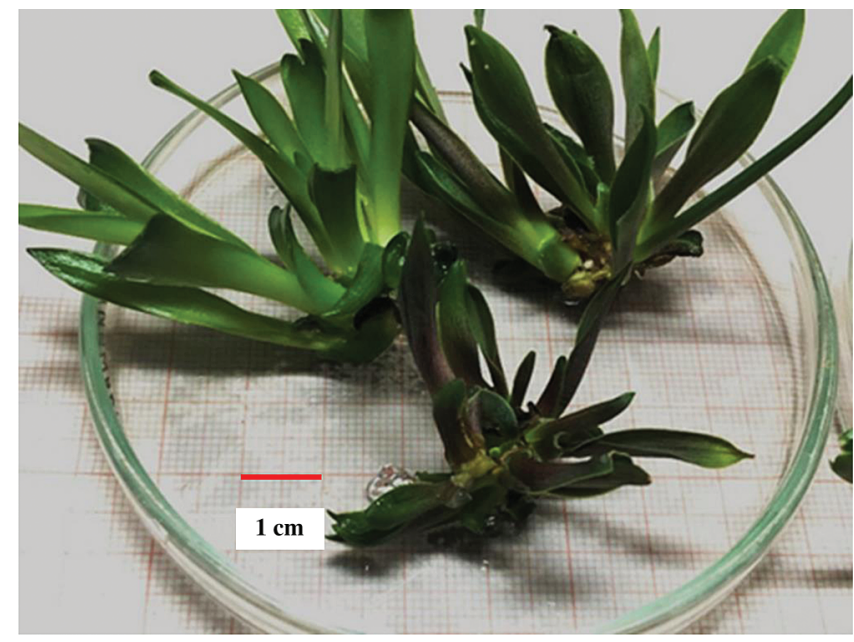

Figure 1: Axillary shoots induced by the addition of BA $(13.2 \mu \mathrm{M})$ in segmented stems of A. tequilana cv. azul, after 6 weeks of culture in a solid MS medium

Regarding the multiplication efficiency, our results are different from those of other authors (Tab. 1). For example, Nikam [40] observed in A. sisalana Perrine that the addition of kinetin $0.5 \mathrm{mg} \mathrm{L}^{-1}$, in the range of 0.2 to $2.0 \mathrm{mg} \mathrm{L}^{-1}$, induced the formation of 5.7 shoots per rhizome-explant. Santacruz-Ruvalcaba et al. [13] observed that in $A$. parrasana Berger, the presence of BA in the medium, in the range of 13.3 to $53.2 \mu \mathrm{M}$, induced the formation from 22 to 48.6 shoots per explant in six weeks. These explants came from shoots obtained by in vitro germinated seeds. The shoots were kept for weeks in a medium containing 2,4-D and BA, similarly to what was reported by Robert et al. [6] for A. fourcroydes. In this study, the medium without BA did not induce the formation of lateral shoots. Similarly, Martínez-Palacios et al. [41] observed in $A$. victoriae-reginae, that the addition of $\mathrm{BA}$ in a range of 2.2 to $8.8 \mu \mathrm{M}$ induced the 
formation of 1.9 to 2.2 shoots per explant; these explants consisted of a complete stem base, which was in vitro generated through seeds. The culture medium without the addition of BA induced the formation of 1.1 shoots per explant and the observations were made during 12 weeks. Then again, Rosales et al. [17] evaluated the effect of different cytokinins: BA (1-3 $\left.\mathrm{mg} \mathrm{L}^{-1}\right), 2 \mathrm{iP}\left(1.0-3.0 \mathrm{mg} \mathrm{L}^{-1}\right)$, kinetin (1.0-3.0 $\mathrm{mg} \mathrm{L}^{-1}$ ), thidiazuron (TDZ 0.1-0.4 $\mathrm{mg} \mathrm{L}^{-1}$ ) and Meta-hydroxybenzyl Adenine (MT 0.5-2.0 $\mathrm{mg} \mathrm{L}^{-1}$ ) on proliferation of lateral shoots in A. cupreata Trel and Berger, A. difformis Berger, A. karwinskii Zucc., A. obscura Schiede and A. potatorum Zucc., using stem bases as explants after 12 weeks of culture. A. cupreata and A. karwinskii (BA 1.5 and $1.0 \mathrm{mg} \mathrm{L}^{-1}$ ) developed 10.5 and 6.1 shoots per explant, respectively. A. difformis and A. obscura (TDZ $0.2 \mathrm{mg} \mathrm{L}^{-1}$ ) provided 8.5 and 11 shoots per explant, correspondingly. A. potatorum (kinetin $3.0 \mathrm{mg} \mathrm{L}^{-1}$ ) produced 6.9 buds per explant. However, this study did not evaluate shoot production in a growth medium without cytokinins. Furthermore, the origin of the shoots used as explants came from seeds.

According to our results, it can be suggested that the exogenous presence of cytokinin is important in the induction of lateral dominance at the base of complete stems of Agave tequilana Weber cv. azul. Likewise, in this Agave species, the sagittal segmentation of stem base inhibits apical dominance. Also, efficiency is increased in both: shoot number and reduction of time to develop each shoot. In summary, the results obtained in this study on Agave tequilana Weber cv. azul are different from results previously published by other researchers (Tab. 1).

\subsection{Multiplication in a Temporary Immersion System (TIS)}

The A. tequilana Weber cv. azul explants, after 12 weeks of incubation in TIS, produced different number of shoots per explant, which were evaluated. The IAA addition $(0.57-5.7 \mu \mathrm{M})$ enhanced the number of lateral shoots, higher IAA concentrations induced the formation of more than 20 shoots per explant (Tab. 4). The shoots depicted a normal differentiation appearance, noticing a shiny cuticle without callus formation at the bases, and without any qualitative malformation appearance or hyperhidrosis (Fig. 2). The lack of hyperhidrosis in the agave shoots is one of the main advantages of our multiplication system since this anomalous growth is a very common phenomenon when agave explants are grown in liquid medium (Fig. 2B. It was observed, by visual inspection, that all multiple shoots grew from the axile between the bases of the leaves). The shoots emerged in an orderly and concentric way, from the tissue located between the bases of the cataphylls. Likewise, the individual shoots depicted the morphology of phytomers, which consist of one or two leaves that surround the apex, a node with the ability to form new lateral buds, and a stem or basal internode that supports the entire shoot (Fig. 2C). These observations support the proposition that the shoots differentiated directly from stem disc tissue and did not occur through a process of adventitious differentiation (Fig. 2D). This study offered a novel, original report [27] of culture in liquid medium for micropropagation of A. tequilana Weber cv. azul, using a RITA $^{\circledR}$ temporary immersion system. The increase in axillary shooting induced by IAA concentration is an effect that had not been previously evaluated. Although IAA was used in a single concentration, it was added to cytokinin treatments $[7,11,16]$ to increase lateral proliferation. In addition, NAA was used in different concentrations with BA to induce adventitious regeneration of $A$. americana, utilizing basal leaf segments [54].

Table 4: Axillary shoot production in A. tequilana cv. azul using segmented stems as explants and growing in RITA $^{\circledR}$ in the presence of BA and IAA

\begin{tabular}{ll}
\hline IAA $\mu \mathrm{M}+(\mathrm{BA} 13.2 \mu \mathrm{M})^{*}$ & Shoot per Explant† \\
\hline 0.57 & $5.33 \pm 0.98 \mathrm{a}$ \\
2.9 & $12.16 \pm 1.68 \mathrm{~b}$ \\
5.1 & $20.60 \pm 1.20 \mathrm{c}$ \\
\hline
\end{tabular}

Note: $*$ The concentration of $13.2 \mu \mathrm{M}$ BA was added to all treatments. $\dagger$ Shapiro-Wilk

Test: $P=0.1612$. Average values \pm standard error with distinctive letters within the column to the right, are significantly different. (Tukey; $\alpha=0.05$ ). 


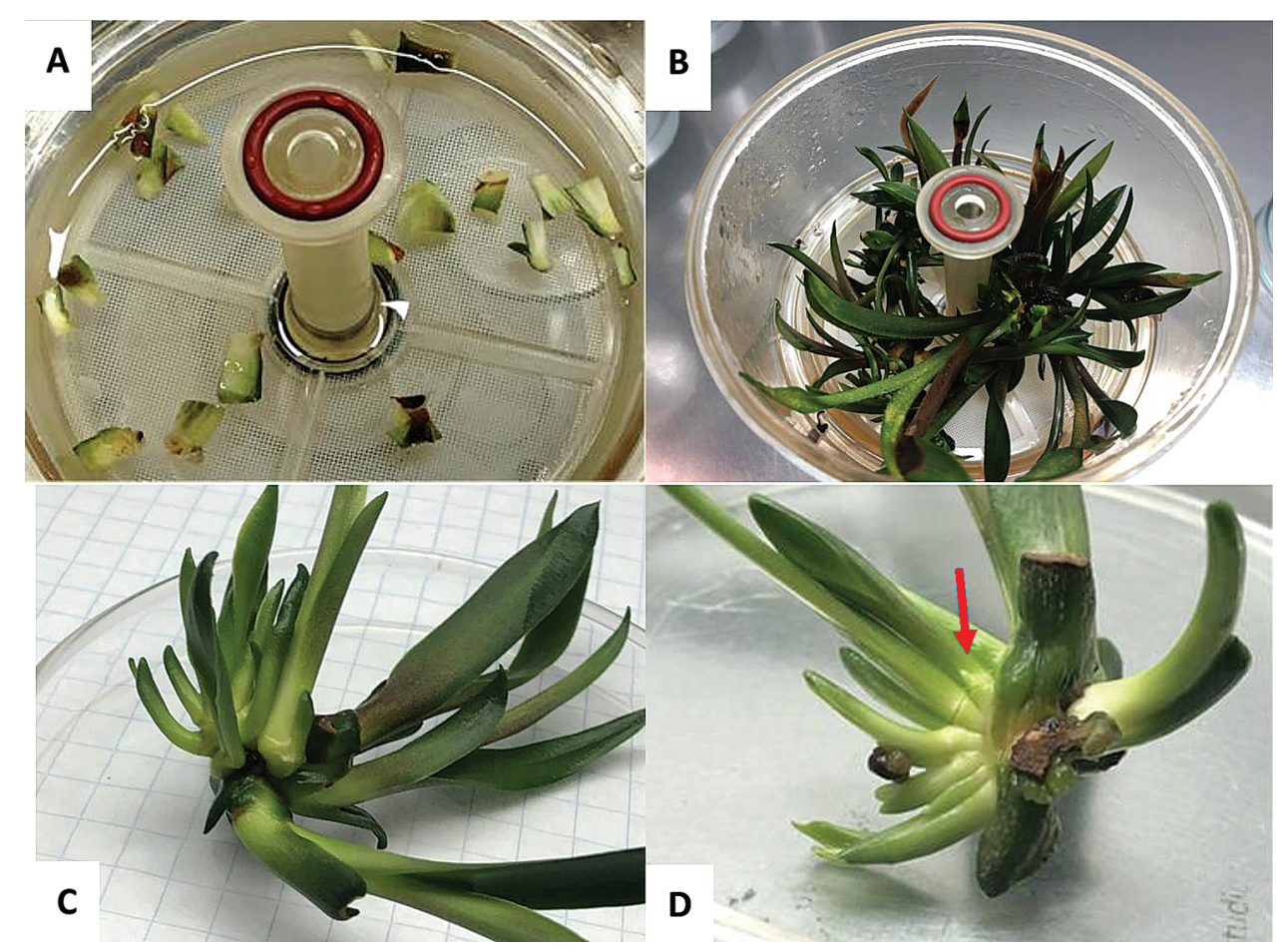

Figure 2: Culture of segmented stems, as explants, of A. tequilana Weber cv. azul (A). Direct formation of multiple axillary shoots within RITA $^{\circledR}$ after 12 weeks in MS liquid medium (B). A segment (C) showing multiple shoots grew from the axile between the bases of the leaves (arrow) (D)

The use of IAA and BA in this study also has a remarkable difference compared to earlier reports. Previously, central stem segments were used, but intact base and apex segments were included. In this way, the explant proliferated in lateral and adventitious buds by adding $0.025 \mathrm{mg} \mathrm{L}^{-1} 2,4-\mathrm{D}$ and $10.0 \mathrm{mg} \mathrm{L}^{-1}$ BA [6]. Likewise, the following regeneration systems were developed through the formation of calli at the apex base, applying pulses of high concentration of 2,4-D $(6.8 \mathrm{mM})$ for three days. Subsequently, the basal cluster of adventitious and apex buds was maintained in a medium containing a combination of $0.113 \mu \mathrm{M}$ $2,4-\mathrm{D}+4.44 \mu \mathrm{M}$ BA [9]. It was also proposed that the multiplication scheme should be the subculture of explants composed of $2-3$ shoots providing BA in the medium $\left[0-12 \mathrm{mg} \mathrm{L}^{-1}(0-53.2 \mu \mathrm{M})\right]$ and 2,4-D [0.001-0.025 $\left.\mathrm{mg} \mathrm{L}^{-1}(0.04-0.11 \mu \mathrm{M})\right][3,14]$.

Our study proposes an alternative to this multiplication scheme, avoiding the use of 2,4-D in A. tequilana Weber cv. azul micropropagation. This is because this synthetic auxin has risks of cytogenetic effects and somaclonal variation, which were observed in several in vitro systems [53,55-58]. In the same way, physiological changes were detected in the Agave plantlets when the successive subcultures were achieved in the presence of 2,4-D [51].

This study retakes the previous research strategies in Agave by (A) segmenting the explant [11] and favoring axillary shooting above the adventitia, and (B) exploring the effect of IAA activity at moderate BA concentrations [16]. In this sense, up to our knowledge, these results have not been previously reported for A. tequilana Weber $\mathrm{cv}$. azul, indicating that together with the sagittal segmentation of the stem, BA activity is important for elimination of apical dominance (Tab. 2). Likewise, the IAA concentration induced the additional increase in axillary shooting. These results emphasize the importance 
of adjusting exogenous auxins and cytokinins on in vitro morphogenic responses $[47,59,60]$. Furthermore, our observations appeared that the handling of the explant and the temporary immersion of $A$. tequilana Weber cv. azul increased proliferation and had considerable development in terms of efficiency. These optimization conditions would foster the development of reliable systems to evaluate multiple modifiable factors in the RITA ${ }^{\circledR}$, or the evaluation and comparison with other available systems in this technology [25,36,37,61-64].

The biochemical mechanism for the induction of lateral shoot proliferation in A. tequilana Weber cv. azul stems is related to the auxin activity, inducing apical dominance according to IAA-polar transport chemiosmotic model [65], and its interaction with cytokinins that promote lateral dominance in orthotropic stems [66]. Cytokinins regulate cell division by affecting the controls that govern cell cycle progression and depend on auxins to participate in cell division by controlling the activity of cyclindependent protein Kinases (CDKs) [67].

The addition of BA, zeatin and kinetin in the media were carried out to evaluate their effectiveness in inducing lateral dominance, given the natural existence of endogenous auxins. Tabs. 2 and 3 clearly show that the exogenous cytokinins induced a lateral dominance effect due to a greater shoot number.

In the liquid culture medium, the exogenous addition of IAA over a relatively high concentration of BA, demonstrated this optimization effect, by increasing the number of lateral shoots, according to the auxin/ cytokinin interaction mechanism [59]. Tab. 4 depicts that the IAA induces lateral shoots that can reach an optimum, given the presence of a relatively high level of BA.

Other important factors in this study are the explant type and the sagittal cut effect. Central stem blocks are used in the most common methods for agave micropropagation (Tab. 1). Robert et al. [14] induced the formation of adventitious shoots on apical cubes of $0.8 \mathrm{~cm}^{3}$ by adding 2,4-D $(0.11 \mu \mathrm{M})$ and BA $(44.4 \mu \mathrm{M})$. They noted that the meristem region produced most of the shoots. They stated that what is needed for induction was the undifferentiated meristematic tissue that lies below. In all the experiments in this study, we consider that the induction of shoots in stem discs has its origin in meristems separated from the central meristem, according to the concept of Steeves et al. [68] and Wardlaw [69]. Although there were no histological studies in this study, the formation of shoots between the leaf bases, without the presence of cytokinins, shows a natural behavior of lateral dominance. This effect is enhanced by exogenous concentrations of cytokinins and is optimized with IAA.

\section{Conclusions}

The in vitro culture of segmented stem discs, as explants, proved to be a simple and efficient technique for the micropropagation of Agave tequilana Weber cv. azul in semi-solid and liquid media. During the establishment stage, sagittal segmentation in the explants, without the presence of plant growth regulators, induced the formation of lateral shoots. The addition of BA or zeatin (17.6-18.4 $\mu \mathrm{M})$ in the medium increased axillary sprouting, inducing the formation of 12.41 shoots on average. In the multiplication stage, subculturing segmented stem discs, without the addition of plant growth regulators, induced the formation of up to four shoots, on average. The addition of BA (4.4-13.2 $\mu \mathrm{M})$ and kinetin $(4.7-9.4 \mu \mathrm{M})$ increased the proliferation efficiency to 13.0 and 20.6 shoots on average, respectively. The cultivation of segmented stems in a RITA $^{\circledR}$ added with BA $(13.2 \mu \mathrm{M})$, induced the formation of 5.33 shoots, on average. The addition and increase of IAA concentration $(0.57-5.1 \mu \mathrm{M})$, in the presence of BA $(13.2 \mu \mathrm{M})$, boosted the multiplication efficiency, generating the formation of up to 20.6 shoots on average. Therefore, we propose that the use of segmented stems combined with the addition of cytokinins and auxins, using solid and liquid media, will promote more efficient micropropagation systems. 
Acknowledgement: We thank to Estefany Alejandra Sanchez Mendoza for her valuable technical support in the plant tissue culture experiments.

Funding Statement: The authors are grateful for the academic support from the Biosciences postgraduate program of the University of Guanajuato and especially, for the technological support of the Autonomous University of Aguascalientes.

Conflicts of Interest: The authors declare that they have no conflicts of interest to report regarding the present study.

\section{References}

1. González, G., Alemán, S., Trujilo, R., Keb, M., Abreu, E. et al. (2004). El cultivo in vitro como alternativa de la recuperación henequenera (Agave fourcroydes). Biotecnologia Aplicada, 21(1), 44-48.

2. Gutiérrez-Mora, A., Ruvalcaba-Ruiz, D., Rodríguez-Domínguez, J. M., Loera-Quezada, M. M., Rodríguez-Garay, B. et al. (2004). Recent advances in the biotechnology of Agave: A cell approach. Recent Research Developments in Cell Biology, 2, 17-66.

3. Rodríguez-Garay, B., Rodríguez-Domínguez, J. M. (2018). Micropropagation of Agave species. In: Ochoa-Alejo, N., Loyola-Vargas, V. M. (Eds.), Methods in molecular biology, vol. 1815, pp. 151-159. New York: Humana Press. DOI 10.1007/978-1-4939-8594-4 8 .

4. Kulus, D. (2014). Micropropagation of selected Agave species. In: Czubenko, M. (Ed.), PhD interdisciplinary journal, pp. 75-84. Bydgoszcz: University of Technology and Life Sciences.

5. Groenewald, E. G., Wessels, D. C. J., Koeleman, A. (1977). Callus formation and subsequent plant regeneration from seed tissue of an Agave species. Zeitschrift für Pflanzenphysiologie, 81(4), 369-373. DOI 10.1016/S0044328X(77)80105-0.

6. Robert, M. L., Herrera, J. L., Contreras, F., Scorer, K. N. (1987). In vitro propagation of Agave fourcroydes Lem. (Henequen). Plant Cell, Tissue and Organ Culture, 8(1), 37-48. DOI 10.1007/BF00040731.

7. Powers, D. E., Backhaus, R. A. (1989). In vitro propagation of Agave arizonica gentry \& weber. Plant Cell, Tissue and Organ Culture, 16(1), 57-60. DOI 10.1007/BF00044072.

8. Hazra, S. K., Das, S., Das, A. K. (2002). Sisal plant regeneration via organogenesis. Plant Cell, Tissue and Organ Culture, 70, 235-240. DOI 10.1023/A:1016517617039.

9. Ramírez-Malagón, R., Borodanenko, A., Pérez-Moreno, L., Salas-Araiza, M. D., Nuñez-Palenius et al. (2008). In vitro propagation of three Agave species used for liquor distillation and three for landscape. Plant Cell, Tissue and Organ Culture, 94(2), 201-207. DOI 10.1007/s11240-008-9405-x.

10. Angeles-Espino, A., Valencia-Botín, A. J., Virgen-Calleros, G., Ramírez-Serrano, C., Paredes-Gutiérrez, L. et al. (2012). Micropropagation of agave (Agave tequilana weber. var. azul) through axillary buds. Tropical and Subtropical Agroecosistems, 15, 693-698.

11. Binh, L. T., Muoi, L. T., Oanh, H. T. K., Thang, T. D., Phong, D. T. (1990). Rapid propagation of agave by in vitro tissue culture. Plant Cell, Tissue and Organ Culture, 23(1), 67-70. DOI 10.1007/BF00116091.

12. Das, T. (1992). Micropropagation of Agave sisalana. Plant Cell, Tissue and Organ Culture, 31(3), 253-255. DOI 10.1007/BF00036233.

13. Santacruz-Ruvalcaba, F., Gutiérrez-Pulido, H., Rodríguez-Garay, B. (1999). Efficient in vitro propagation of agave parrasana berger. Plant Cell, Tissue and Organ Culture, 56(3), 163-167. DOI 10.1023/A:1006232911778.

14. Robert, L. M., Herrera-Herrera, J. L., Castillo, E., Ojeda, G., Herrera-Alamillo, M. A. (2006). An efficient method for the micropropagation of Agave species. In: Loyola-Vargas, V. M., Vázquez-Flota, F. (Eds.), Methods in Molecular biology, pp. 165-178. New Jersey: Humana Press. DOI 10.1385/1-59259-959-1.

15. Valenzuela-Sánchez, K. K., Juárez-Hernández, R. E., Cruz-Hernández, A., Olalde-Portugal, V., Valverde, M. E. et al. (2006). Plant regeneration of Agave tequilana by indirect organogenesis. In Vitro Cellular \& Developmental Biology-Plant, 42(4), 336-340. DOI 10.1079/IVP2006788. 
16. Silos-Espino, H., González-Cortés, N., Carrillo-López, A., Guevara-Lara, F., Valverde-González, M. E. et al. (2007). Chemical composition and in vitro propagation of Agave salmiana "Gentry". Journal of Horticultural Science and Biotechnology, 82(3), 355-359. DOI 10.1080/14620316.2007.11512242.

17. Rosales, M. S. D., Solís, Á. G. A., Méndez, N. L. V., Balch, E. P. M. (2008). Efecto de citocininas en la propagación in vitro de agaves mexicanos. Revista Fitotecnia Mexicana, 31(4), 317-322. DOI 10.35196/ rfm.2008.4.317.

18. Enríquez del Valle, J. R., Carrillo-Castañeda, G., Rodríguez de la O, J. L. (2005). Sales inorgánicas y ácido indolbutírico en el enraizado in vitro de brotes de agave angustifolia. Revista Fitotecnia Mexicana, 28(2), 175-178.

19. Rodríguez-Garay, B., Gutiérrez-Mora, A., Acosta-Dueñas, B. (1996). Somatic embryogenesis of Agave victoriareginae moore. Plant Cell, Tissue and Organ Culture, 46(1), 85-87. DOI 10.1007/BF00039700.

20. Nikam, T. D., Bansude, G. M., Aneesh Kumar, K. C. (2003). Somatic embryogenesis in sisal (Agave sisalana perr. Ex engelm). Plant Cell Reports, 22, 188-194. DOI 10.1007/s00299-003-0675-9.

21. Portillo, L., Santacruz-Ruvalcaba, F., Gutiérrez-Mora, A., Rodríguez-Garay, B. (2007). Somatic embryogenesis in Agave tequilana weber cultivar azul. In Vitro Cellular \& Developmental Biology-Plant, 43(6), 569-575. DOI 10.1007/s11627-007-9046-5.

22. Tejavathi, D. H., Rajanna, M. D., Sowmya, R., Gayathramma, K. (2007). Induction of somatic embryos from cultures of Agave veracruz. In Vitro Cellular \& Developmental Biology-Plant, 43(5), 423-428. DOI 10.1007/ s11627-007-9088-8.

23. Andrijany, V. S., Indrayanto, G., Soehono, L. A. (1998). Simultaneous effect of calcium, magnesium, copper and cobalt ions on sapogenin steroids content in callus cultures of Agave amaniensis. Plant Cell, Tissue and Organ Culture, 55(2), 103-108. DOI 10.1023/A:1006119600153.

24. Puente-Garza, C. A., Gutiérrez-Mora, A., García-Lara, S. (2015). Micropropagation of Agave salmiana: Means to production of antioxidant and bioactive principles. Frontiers in Plant Science, 6, 1-9. DOI 10.3389/ fpls.2015.01026.

25. Etienne, H., Berthouly, M. (2002). Temporary immersion systems in plant micropropagation. Plant Cell, Tissue and Organ Culture, 69(3), 215-231. DOI 10.1023/A:1015668610465.

26. González, E. J. (2005). Mass propagation of tropical crops in temporary immersion systems. In: Hvoslef-Eide, A. K., Preil, W. (Eds.), Liquid culture systems for in vitro plant propagation, pp. 197-211. Netherlands: Springer. DOI 10.1007/1-4020-3200-5-12.

27. Paula, M. W. (2012). The status of temporary immersion system (TIS) technology for plant micropropagation. African Journal of Biotechnology, 11(76), 14025-14035. DOI 10.5897/AJB12.1693.

28. Georgiev, V., Schumann, A., Pavlov, A., Bley, T. (2014). Temporary immersion systems in plant biotechnology. Engineering in Life Sciences, 14(6), 607-621. DOI 10.1002/elsc.201300166.

29. Teisson, C., Alvard, D. (1995). A new concept of plant in vitro cultivation liquid medium: Temporary immersion. In: Terzi, M., Cella, R., Falavigna, A. (Eds.), Current issues in plant molecular and cellular biology. Current Plant Science and Biotechnology in Agriculture, vol. 22, pp. 105-110. Dordrecht: Springer. DOI 10.1007/978-94-0110307-7_12.

30. Etienne, H. (2005). Somatic embryogenesis protocol: Coffee (Coffea Arabica L. and C. Canephora P.). In: Jain, S. M., Gupta, P. K. (Eds.), Protocol for somatic embryogenesis in woody plants, pp. 167-179. Netherlands: Springer.

31. Hempfling, T., Preil, W. (2005). Application of a temporary immersion system in mass propagation of phalaenopsis. Liquid Culture Systems for in Vitro Plant Propagation, 2002, 231-242. DOI 10.1007/1-40203200-5-15.

32. Mordocco, A. M., Brumbley, J. A., Lakshmanan, P. (2009). Development of a temporary immersion system (RITA®) for mass production of sugarcane (Saccharum spp. interspecific hybrids). In Vitro Cellular \& Developmental Biology-Plant, 45(4), 450-457. DOI 10.1007/s11627-008-9173-7.

33. Vidal, N., Blanco, B., Cuenca, B. (2015). A temporary immersion system for micropropagation of axillary shoots of hybrid chestnut. Plant Cell, Tissue and Organ Culture, 123(2), 229-243. DOI 10.1007/s11240-015-0827-y. 
34. González-Olmedo, J. L., Fundora, Z., Molina, L. A., Abdulnour, J., Desjardins, Y. et al. (2005). New contributions to propagation of pineapple (Ananas comosus L. merr.) in temporary immersion bioreactors. In Vitro Cellular \& Developmental Biology-Plant, 41(1), 87-90. DOI 10.1079/IVP2004603.

35. Farahani, F., Majd, A. (2012). Comparison of liquid culture methods and effect of temporary immersion bioreactor on growth and multiplication of banana (Musa, cv. Dwarf Cavendish). African Journal of Biotechnology, 11(33), 8302-8308. DOI 10.5897/ajb11.2020.

36. Ramírez-Mosqueda, M. A., Iglesias-Andreu, L. G. (2016). Evaluation of different temporary immersion systems $\left(\mathrm{BIT}^{\circledR}, \mathrm{BIG}\right.$, and RITA $\left.^{\circledR}\right)$ in the micropropagation of Vanilla planifolia Jacks. In Vitro Cellular \& Developmental Biology-Plant, 52(2), 154-160. DOI 10.1007/s11627-015-9735-4.

37. Bello-Bello, J. J., Cruz-Cruz, C. A., Pérez-Guerra, J. C. (2019). A new temporary immersion system for commercial micropropagation of banana (Musa AAA cv. Grand Naine). In Vitro Cellular \& Developmental Biology-Plant, 55, 313-320. DOI 10.1007/s11627-019-09973-7.

38. George, F. E. (1993). Plant propagation by tissue culture Part I-The technology. England: Exegetics, Ltd.

39. Área Agrícola de Casa Sauza (2017). Micropropagación del agave azul. https://www.casasauza.com/procesostequila-sauza/micropropagacion-agave-azul.

40. Nikam, T. D. (1997). High frequency shoot regeneration in Agave sisalana. Plant Cell, Tissue and Organ Culture, 51(3), 225-228. DOI 10.1023/A:1005976304198.

41. Martínez-Palacios, A., Ortega-Larrocea, M. P., Chávez, V. M., Bye, R. (2003). Somatic embryogenesis and organogenesis of Agave victoriae-reginae. Plant Cell, Tissue and Organ Culture, 74, 135-142. DOI 10.1023/ A:1023933123131.

42. Ayabe, M., Sumi, S. (1998). Establishment of a novel tissue culture method, stem-disc culture, and its practical application to micropropagation of garlic (Allium sativum L.). Plant Cell Reports, 17(10), 773-779. DOI $10.1007 / \mathrm{s} 002990050481$.

43. Hartman, H. T., Kester, D. E. (1987). Plant propagation, principles and practices. México: Prentice Hall Inc.

44. Miller, W. B., Adkins, J. A., Preece, J. E. (2008). Propagating selected flower bulb species. In: Beyl, C. A., Trigiano, R. N. (Eds.), Plant propagation, concepts and laboratory exercises, pp. 311-318. USA: CRC Press.

45. Ramos-Castellá, A., Iglesias-Andreu, L. G., Bello-Bello, J., Lee-Espinosa, H. (2014). Improved propagation of vanilla (Vanilla planifolia jacks. ex andrews) using a temporary immersion system. In Vitro Cellular \& Developmental Biology-Plant, 50(5), 576-581. DOI 10.1007/s11627-014-9602-8.

46. Xue, H., Araki, H., Shi, L., Yakuwa, T. (1991). Somatic embryogenesis and plant regeneration in basal plate and receptacle derived-callus cultures of garlic (Allium sativum L.). Journal of the Japanese Society for Horticultural Science, 60(3), 627-634. DOI 10.2503/jjshs.60.627.

47. Thimann, K. V., Skoog, F. (1933). Studies on the growth hormone of plants. Proceedings of the National Academy of Sciences, 19(7), 714-716. DOI 10.1073/pnas.19.7.714.

48. Skoog, F., Thimann, K. V. (1934). Further experiments on the inhibition of the development of lateral buds by growth hormone. Proceedings of the National Academy of Sciences, 20(8), 480-485. DOI 10.1073/pnas.20.8.480.

49. Li, C., Bangerth, F. (2003). Stimulatory effect of cytokinins and interaction with IAA on the release of lateral buds of pea plants from apical dominance. Journal of Plant Physiology, 160(9), 1059-1063. DOI 10.1078/0176-161701042.

50. Torres-Morán, M. I., Escoto-Delgadillo, M., Molina-Moret, S., Rivera-Rodríguez, D. M., Velasco-Ramírez, A. P. et al. (2010). Assessment of genetic fidelity among agave tequilana plants propagated asexually via rhizomes versus in vitro culture. Plant Cell, Tissue and Organ Culture, 103(3), 403-409. DOI 10.1007/s11240-0109777-6.

51. Duarte-Aké, F., Castillo-Castro, E., Pool, F. B., Espadas, F., Santamaría, J. M. et al. (2016). Physiological differences and changes in global DNA methylation levels in Agave angustifolia Haw. albino variant somaclones during the micropropagation process. Plant Cell Reports, 35(12), 1-14. DOI 10.1007/s00299-0162049-0. 
52. Us-Camas, R., Castillo-Castro, E., Aguilar-Espinosa, M., Limones-Briones, V., Rivera-Madrid, R. et al. (2017). Assessment of molecular and epigenetic changes in the albinism of Agave angustifolia Haw. Plant Science, 263, 156-167. DOI 10.1016/j.plantsci.2017.07.010.

53. Garcia, C., de Almeida, F., Costa, A. A., Britto, M., Valle, D. et al. (2019). Abnormalities in somatic embryogenesis caused by 2,4-D: An overview. Plant Cell, Tissue and Organ Culture, 137(2), 193-212. DOI 10.1007/s11240-019-01569-8.

54. Chen, Y., Chen, X., Hu, F., Yang, H., Yue, L. et al. (2014). Micropropagation of Agave americana. HortScience, 49(3), 320-327. DOI 10.21273/hortsci.49.3.320.

55. Nehra, N. S., Kartha, K. K., Stushnott, C., Giles, K. L. (1992). The influence of plant growth regulator concentrations and callus age on somaclonal variation in callus culture regenerants of strawberry. Plant Cell, Tissue and Organ Culture, 29, 257-268. DOI 10.1007/BF00034361.

56. Bouman, H., de Klerk, G. J. (2001). Measurement of the extent of somaclonal variation in begonia plants regenerated under various conditions. comparison of three assays. Theoretical and Applied Genetics, 102, 111117. DOI $10.1007 / \mathrm{s} 001220051625$.

57. Ahmed, E. U., Hayashi, T., Yazawa, S. (2004). Auxins increase the occurrence of leaf-colour variants in Caladium regenerated from leaf explants. Scientia Horticulturae, 100, 153-159. DOI 10.1016/j.scienta.2003.08.012.

58. Mohanty, S., Panda, M. K., Subudhi, E., Nayak, S. (2008). Plant regeneration from callus culture of Curcuma aromatica and in vitro detection of somaclonal variation through cytophotometric analysis. Biologia Plantarum, 52, 783-786. DOI 10.1007/s10535-008-0153-x.

59. Skoog, F., Miller, C. O. (1957). Chemical regulation of growth and organ formation in plant tissues cultured in vitro. Symposia of the Society for Experimental Biology, 11, 118-130.

60. Murashige, T., Skoog, F. (1962). A revised medium for rapid growth and bio assays with tobacco tissue cultures. Physiologia Plantarum, 15(3), 473-497. DOI 10.1111/j.1399-3054.1962.tb08052.x.

61. Vives, K., Andújar, I., Lorenzo, J. C., Concepción, O., Hernández, M. et al. (2017). Comparison of different in vitro micropropagation methods of Stevia rebaudiana B. including temporary immersion bioreactor (BIT®). Plant Cell, Tissue and Organ Culture, 131(1), 195-199. DOI 10.1007/s11240-017-1258-8.

62. Bello-Bello, J. J., Cruz-Cruz, C. A., Pérez-Guerra, J. C. (2019). A new temporary immersion system for commercial micropropagation of banana (Musa AAA cv. Grand Naine). In Vitro Cellular and Developmental Biology-Plant, 55, 313-320. DOI 10.1007/s11627-019-09973-7.

63. Monja-Mio, K. M., Olvera-Casanova, D., Herrera-Herrera, G., Herrera-Alamillo, M. Á., Sánchez-Teyer, F. L. et al. (2020). Improving of rooting and ex vitro acclimatization phase of Agave tequilana by temporary immersion system (BioMINT $\left.{ }^{\mathrm{TM}}\right)$. In Vitro Cellular \& Developmental Biology-Plant, 56(5), 662-669. DOI 10.1007/ s11627-020-10109-5.

64. Chávez-Ortiz, L. I., Morales-Domínguez, J. F., Rodríguez-Sahagún, A., Pérez-Molphe-Balch, E. (2021). In vitro propagation of Agave guiengola gentry using semisolid medium and temporary immersion bioreactors. PhytonInternational Journal of Experimental Botany, 90(3), 1003-1013. DOI 10.32604/phyton.2021.012862.

65. Jacobs, M., Gilbert, S. F. (1983). Basal localization of the presumptive auxin transport carrier in pea stem cells. Science, 220(4603), 1297-1300. DOI 10.1126/science.220.4603.1297.

66. Gocal, G. F. W., Pharis, R. P., Yeung, E. C., Pearce, D. (1991). Changes after decapitation in concentrations of indole-3-acetic acid and abscisic acid in the larger axillary bud of Phaseolus vulgaris L. cv. tender green. Plant Physiology, 95(2), 344-350. DOI 10.1104/pp.95.2.344.

67. Taiz, L., Zeiger, E. (2002). Plant physiology. Massachusetts: Sinauer Associates.

68. Steeves, T. A., Sussex, I. M. (1989). Patterns in plant development. Cambridge: C. U. Press.

69. Wardlaw, C. W. (1943). Experimental and analytical studies of pteridophytes II. Experiment observations of development of buds in onoclea sensibilis and in species of dryopteris. Annals of Botany (London), 7, 357377. DOI 10.1093/oxfordjournals.aob.a088545. 